OPEN ACCESS

Edited by:

Laurent Dufossé,

Université de la Réunion, France

Reviewed by:

C. K. Venil,

Anna University, India

Ramesh Chatragadda,

National Institute of Oceanography

(CSIR), India

*Correspondence:

Jonathan D. Awaya

awayaj@hawaii.edu

Specialty section

This article was submitted to

Sustainable Food Processing,

a section of the journal

Frontiers in Sustainable Food Systems

Received: 29 August 2020 Accepted: 27 November 2020 Published: 18 December 2020

Citation:

Sakai-Kawada FE, Ip CG, Hagiwara KA, Nguyen H-YX, Yakym C-JAV, Helmkampf $M$, Armstrong EE and Awaya JD (2020) Characterization of

Prodiginine Pathway in Marine Sponge-Associated Pseudoalteromonas sp. PPB1 in Hilo, Hawai'i.

Front. Sustain. Food Syst. 4:600201. doi: 10.3389/fsufs.2020.600201

\section{Characterization of Prodiginine Pathway in Marine Sponge-Associated Pseudoalteromonas sp. PPB1 in Hilo, Hawai'i}

Francis E. Sakai-Kawada 1,2 , Courtney G. I ${ }^{3}$, Kehau A. Hagiwara ${ }^{4}$, Hoang-Yen X. Nguyen ${ }^{5}$, Christopher-James A. V. Yakym ${ }^{5}$, Martin Helmkampf ${ }^{5}$, Ellie E. Armstrong ${ }^{6}$ and Jonathan D. Awaya ${ }^{1,7 *}$

${ }^{1}$ Department of Molecular Biosciences and Bioengineering, College of Tropical Agriculture and Human Resources, University of Hawai'i at Mānoa, Honolulu, HI, United States, ${ }^{2}$ Chemistry Program, School of Natural Sciences and Mathematics, Chaminade University of Honolulu, Honolulu, HI, United States, ${ }^{3}$ John A. Burns School of Medicine, University of Hawai'i at Mānoa, Honolulu, HI, United States, ${ }^{4}$ Chemical Sciences Division, National Institute of Standards and Technology, Charleston, SC, United States, ${ }^{5}$ Tropical Conservation Biology and Environmental Science, University of Hawai'i at Hilo, Hilo, HI, United States, ${ }^{6}$ Department of Biology, Stanford University, Stanford, CA, United States, ${ }^{7}$ Department of Biology, College of Natural and Health Sciences, University of Hawai'i at Hilo, Hilo, HI, United States

Interest in bioactive pigments stems from their ecological role in adaptation, as well as their applications in various consumer products. The production of these bioactive pigments can be from a variety of biological sources, including simple microorganisms that may or may not be associated with a host. This study is particularly interested in the marine sponges, which have been known to harbor microorganisms that produce secondary metabolites like bioactive pigments. In this study, marine sponge tissue samples were collected from Puhi Bay off the Eastern shore of Hilo, Hawai'i and subsequently were identified as Petrosia sp. with red pigmentation. Using surface sterilization and aseptic plating of sponge tissue samples, sponge-associated microorganisms were isolated. One isolate (PPB1) produced a colony with red pigmentation like that of Petrosia sp., suggesting an integral relationship between this particular isolate and the sponge of interest. 16S characterization and sequencing of PPB1 revealed that it belonged to the Pseudoalteromonas genus. Using various biological assays, both antimicrobial and antioxidant bioactivity was shown in Pseudoalteromonas sp. PPB1 crude extract. To further investigate the genetics of pigment production, a draft genome of PPB1 was sequenced, assembled, and annotated. This revealed a prodiginine biosynthetic pathway and the first cited-incidence of a prodiginine-producing Pseudoalteromonas species isolated from a marine sponge host. Further understanding into the bioactivity and biosynthesis of secondary metabolites like pigmented prodiginine may uncover the complex ecological interactions between host sponge and microorganism.

Keywords: pseudoalteromonas, marine sponge, prodiginine, prodigiosin, pigments, marine bacteria 


\section{INTRODUCTION}

Interest in bioactive pigment production and isolation has been on the rise due to their versatile uses in cosmetics, food supplements, pharmaceuticals, and textile dyes (Tuli et al., 2015; Hernández-Almanza et al., 2017; Ramesh et al., 2019b). Focus has shifted from synthetic pigments to natural pigments for industrial application because of their sustainability and high yield in production, non-toxic nature, and low-impact on the environment (Ramesh et al., 2019a,b). These natural pigments are derived from various biological sources including invertebrates (e.g., carotenoids, indigotins), plants (e.g., carotenoids, anthocyanins), microorganisms (e.g., prodiginines, violacein), and contribute key ecological roles such as defense against environmental adaptations and protection against predation (Bandaranayake, 2006; Venil et al., 2014; Leong et al., 2018; Tan et al., 2020).

Marine sponges are an essential component of coral reefs, providing structural support and biodiversity as well as contributing to nutrient cycling (Diaz and Rützler, 2001). Sponges have been known to harbor microorganisms that produce a variety of biologically active compounds, including bioactive pigments (Bowman, 2007; Webster and Taylor, 2012). Although sponges lack an overall muscular and nervous system, they are still able to sense and respond to changes within their environment. This may be due to their siliceous spicule system, which has been hypothesized to work as a potential networking system in place of the nervous system through the use of cryptochrome-based photoreception (Perović et al., 1999). Current spongology classifies sponges based on one of three types of spicule composition: (i) calcium carbonate (Calcarea), (ii) glass, siliceous (Hexactinellida), or (iii) spongin (Demospongiae) (Pallela et al., 2011).

With the growing interest in preserving coral reefs, more studies have been performed to investigate the sponge's role within the reef ecosystem. Sponges have been found to not only contribute to the biodiversity and biomass but also provide sources for nutrient and silicon cycling (Diaz and Rützler, 2001; Maldonado et al., 2005). In addition, they offer shelter for invertebrates and are often a link between benthic and pelagic communities.

Marine sponges are greatly impacted by climate change and the new environmental stressors imposed on them, two of which include ocean warming and acidification. Thermal stress in particular can decrease efficacy of defense mechanisms, leading to increased mortality due to pathogens and diseases. In addition, ocean warming can lead to species invasion, shifts in species' latitudinal ranges, and bleaching (Carballo and Bell, 2017).

Bleaching causes deterioration of inner sponge tissue and leads to eminent sponge mortality (Angermeier et al., 2011). Major causes for bleaching include an influx of visible and ultraviolet radiation, freshwater dilution, sedimentation, and introduction of pollutants (Webster, 2007). Aside from the many abiotic factors, the sponge must also deter predators, such as fish (Dunlap and Pawlik, 1996), molluscs (Pawlik et al., 1988), echinoderms (Waddell and Pawlik, 2000), and urchins (Ayling, 1981), as well as compete for space in a constant battle of arms against other marine organisms within the reef ecosystem (Alino et al., 1992; Aerts, 2000). Due to the sponge's simplistic anatomy, it is limited in its capability to protect itself from many of these environmental constraints (Bramhachari et al., 2016).

Sponges have not developed specialized tissues due to its simplistic evolutionary structure, which limits its capability to form a sophisticated immune system. Current studies have shown a spotlight on the sponge innate immunity, demonstrating its use of toll-like receptors or nucleotide-binding domain and leucine-rich repeats for recognition of foreign materials (Wiens et al., 2005, 2007; Yuen et al., 2013). However, there has been no indication of adaptive immunity, suggesting an alternate mechanism of protection against infections.

In recent years, emphasis has been placed on the sponge microbiome and the crucial role it has in host defense (Hentschel et al., 2002; Goldberg, 2013). However, the question has been how these sponges select and obtain many of their symbionts. Three models have been proposed in microbial acquisition: (1) vertical transmission, (2) horizontal transmission, and (3) leaky vertical transmission or mixed mode of transmission, which utilizes a combination of vertical and horizontal transmission (Schmitt et al., 2008; de Oliveira et al., 2020). Vertical transmission describes the microbial acquisition primarily from parent to progeny, horizontal transmission acquires their microbiome from the environment, whereas leaky vertical transmission acquires their microbial community from both their parent and environment.

The associated microorganisms compete for space and resources within the sponge tissue while providing their host the tools necessary to protect itself from disease, predation, and UV irradiation. The bacterial genus, Pseudoalteromonas has been associated with harboring within various hosts as well as with producing numerous bioactive pigments (Bowman, 2007; Ramesh et al., 2019b; Sakai-Kawada et al., 2019). One example includes Pseudoalteromonas luteoviolacea which was isolated from a marine sponge, Iotrochota protea, and was shown to produce the pigment, violacein (Sakai-Kawada et al., 2016). Violacein has demonstrated both antibiotic and antiprotozoal activities that could benefit both itself and its host (Soliev et al., 2011).

This study focused on a marine sponge that was collected in Puhi Bay, Hilo, Hawai'i on June 5, 2013 from a depth of $3 \mathrm{~m}$ (Figure 1). The marine sponge tissue expressed a red-purple hue and was characterized as belonging to the genus, Petrosia sp. (Figure 2). Various microbial colonies were isolated from the sponge tissue after surface sterilization. One isolate (PBB1) expressed a red pigment under certain conditions. Through $16 \mathrm{~S}$ rRNA sequencing and characterization this isolate clustered closely with the genus Pseudoalteromonas.

The aims of this study were (i) to assay the antibacterial and antioxidant biological activity of PPB1 and (ii) to characterize various biosynthetic gene clusters involved in secondary metabolite and pigment production.

\section{MATERIALS AND METHODS}

\section{Bacterial Isolation and Culture Conditions}

All media, glassware, and other reagents were sterilized before use. Approximately $5 \mathrm{~g}$ of sponge tissue was surface sterilized 


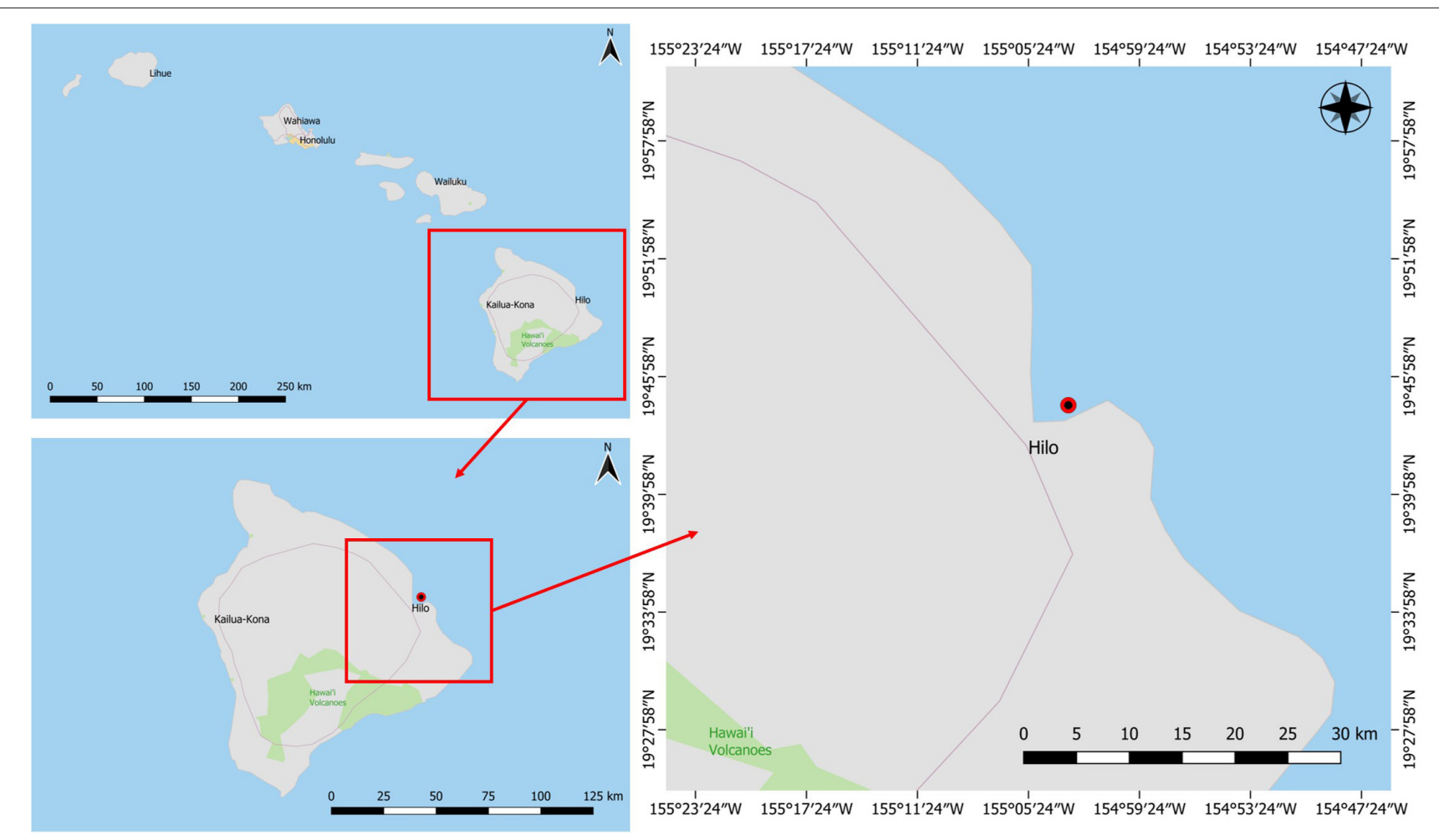

FIGURE 1 | Marine sponge (Petrosia) collection site in Puhi Bay on Hawai'i Island.

with $70 \%$ ethanol (EtOH) and air-dried. Each 5-g sample was sliced to $\sim 1 \mathrm{~cm}$ in thickness and set on marine agar (MA) (Difco) to incubate for 7 days at ambient lab temperature $\left(22-25^{\circ} \mathrm{C}\right)$. In addition, $\sim 5 \mathrm{~g}$ of sponge tissue was surface sterilized with $70 \%$ $\mathrm{EtOH}$, air-dried, and the sponge surface was spread on MA plates as a negative control for outside bacteria growth. Sponges were observed for different microbial growth-based on color, colony morphology, and other distinguishing characteristics.

Bacterial strains used in this study are described in Table $\mathbf{1 .}$ Unless stated otherwise, Pseudoalteromonas sp. PPB1 was grown and maintained on agar or in liquid marine media containing $0.5 \%$ peptone in prepared artificial seawater. All B. cereus, E. coli, and $S$. aureus strains were grown and maintained on LB agar or LB broth ( $1 \%$ peptone, $0.5 \%$ yeast extract, $0.5 \% \mathrm{NaCl}$ ).

\section{Electron Microscopy}

PPB1 cells were grown on MA and resuspended in sterile autoclaved $\mathrm{ddH}_{2} \mathrm{O}$, centrifuged, and decanted with $\mathrm{ddH}_{2} \mathrm{O} 3$ times. Cells were fixed with $4 \%$ glutaraldehyde in $0.1 \mathrm{~mol} / \mathrm{L}$ sodium cacodylate with $0.35 \mathrm{~mol} / \mathrm{L}$ sucrose, $\mathrm{pH} 7.6$, for $1 \mathrm{~h}$. The cell mixture was loaded onto a $0.2 \mu \mathrm{m}$ filter and the liquid was filtered through. Cells were washed in $0.1 \mathrm{~mol} / \mathrm{L}$ sodium cacodylate with $0.44 \mathrm{~mol} / \mathrm{L}$ sucrose, two times for $20 \mathrm{~min}$. Cells were then dehydrated in a graded EtOH series of 30, 50, 70, 85, and $95 \%$, two times for $3 \mathrm{~min}$ at each dilution. Cells were dried with $100 \% \mathrm{EtOH}$ for $10 \mathrm{~min}$, three times. Cells were dried to a critical point with hexamethyldisilazane. The filter containing the prepared cells was mounted on conductive carbon tape that was mounted on an aluminum disc. The silver polish was dotted from the edge of the disk to the edge of the filter. The cells were gold sputter-coated for $60 \mathrm{~s}$ in a vacuum chamber. Cells were visualized using Hitachi S-3400N Variable Pressure Scanning Electron Microscope.

\section{TA Cloning and Determination of 16S rRNA Gene Sequence}

Genomic DNA was isolated using the UltraClean microbial DNA isolation kit (Mo Bio) according to the provided protocol. Polymerase chain reaction (PCR) amplification of the $16 \mathrm{~S}$ rRNA was performed using primers 27F and 1492R (Table 2) (Kennedy et al., 2009). The PCR was carried out under the following conditions: initialization at $94^{\circ} \mathrm{C}$ for $15 \mathrm{~min}$, 30 cycles of denaturation at $94^{\circ} \mathrm{C}$ for $1 \mathrm{~min}$, annealing at $50^{\circ} \mathrm{C}$ for $1 \mathrm{~min}$, and elongation at $72^{\circ} \mathrm{C}$ for $2 \mathrm{~min}$, followed by a final extension at $72^{\circ} \mathrm{C}$ for $10 \mathrm{~min}$ and hold at $10^{\circ} \mathrm{C}$ for $11 \mathrm{~min}$.

The PCR product was run on a $1.5 \%$ agarose gel run at $90 \mathrm{~V}$ for $\sim 75 \mathrm{~min}$ to confirm the presence of the gene product. The PCR product was cleaned up using the Wizard SV gel and PCR clean-up system according to the provided protocol. The PCR product was then ligated into a pGEM-T easy vector and incubated overnight at $4^{\circ} \mathrm{C}$.

TOP10 cells were incubated in LB broth $(10 \mathrm{~g} / \mathrm{L}$ tryptone, $5 \mathrm{~g} / \mathrm{L}$ yeast extract, $10 \mathrm{~g} / \mathrm{L} \mathrm{NaCl}, \mathrm{pH} 7.5)$ at $37^{\circ} \mathrm{C}$ and shaken 


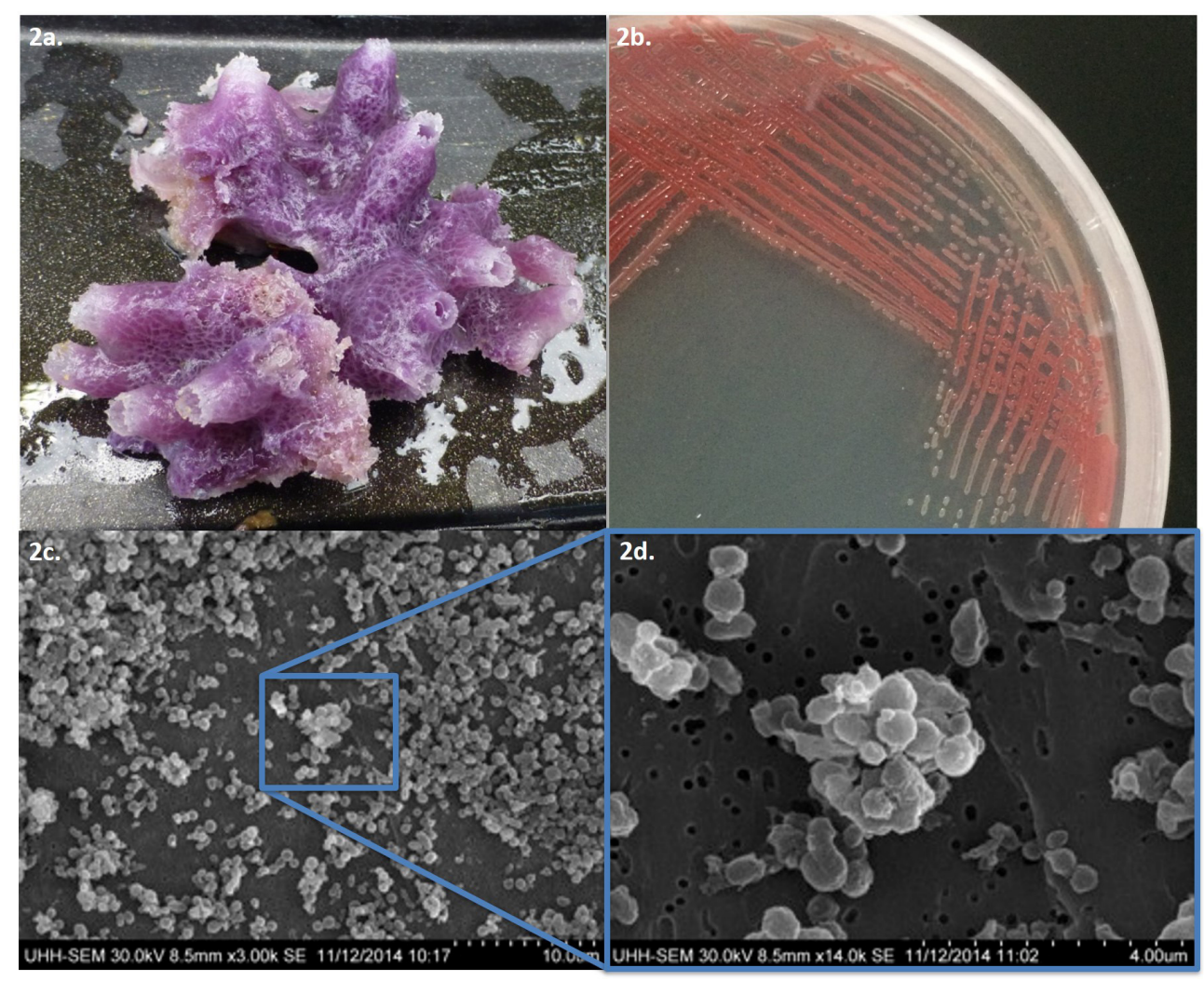

FIGURE 2 | (a) Tissue sample of Petrosia species and (b) pigmented microbial isolate PPB1.

(c) Scanning electron microscope images of Pseudoalteromonas PPB1 field of bacteria and (d) magnified cluster of bacteria.

at $16.8 \mathrm{rad} / \mathrm{s}$ overnight. Hundred $\mu \mathrm{L}$ of the overnight grown TOP10 cells were inoculated in $10 \mathrm{~mL}$ of fresh $\mathrm{LB}$ broth and incubated at $37^{\circ} \mathrm{C}$ in a shaker at $16.8 \mathrm{rad} / \mathrm{s}$ for $\sim 3 \mathrm{~h}$-until the $\mathrm{OD}_{600}=0.5$. The cells were placed on ice for $15 \mathrm{~min}$ and spun at $523.5 \mathrm{rad} / \mathrm{s}$ for $10 \mathrm{~min}$ at $4^{\circ} \mathrm{C}$. The supernatant was discarded, and the cells were resuspended in an equal volume of $0.1 \mathrm{~mol} / \mathrm{L} \mathrm{CaCl}_{2}$ at $4{ }^{\circ} \mathrm{C}$ by gently shaking. The cells were spun again at $523.5 \mathrm{rad} / \mathrm{s}$ for $10 \mathrm{~min}$ and resuspended in onetenth the volume with $0.1 \mathrm{~mol} / \mathrm{L} \mathrm{CaCl}_{2}$ at $4^{\circ} \mathrm{C}$ by gently shaking. Two $\mu \mathrm{L}$ ligation reaction was added to $50 \mu \mathrm{L}$ of competent cells and mixed gently. The cells were placed on ice for $20 \mathrm{~min}$ and submerged in a water bath at $42^{\circ} \mathrm{C}$ for $50 \mathrm{~s}$. The cells were immediately returned to the ice for $2 \mathrm{~min}$. Five-hundred $\mu \mathrm{L}$ of $\mathrm{LB}$ broth was added and incubated for $1 \mathrm{~h}$ at $37^{\circ} \mathrm{C}$ and shaken at $16.8 \mathrm{rad} / \mathrm{s}$.

Transformants were selected using blue-white screening on LB agar supplemented with $15 \mathrm{mg} / \mathrm{L}$ ampicillin and $0.06 \% \mathrm{v} / \mathrm{v}$ Chromomax overnight at $37^{\circ} \mathrm{C}$ (Green and Sambrook, 2019). White colonies were selected and incubated overnight at $37^{\circ} \mathrm{C}$ at $16.8 \mathrm{rad} / \mathrm{s}$ in LB broth supplemented with $15 \mathrm{mg} / \mathrm{L}$ ampicillin. The plasmid was isolated from the transformant cells using the Promega PureYield plasmid miniprep system according to the provided protocol. The plasmid was digested using EcoRI and ran on a $1.5 \%$ agarose gel to confirm the presence of the ligated gene product.

\section{Non-ribosomal Peptide Synthase (NRPS) and Polyketide Synthase (PKS) Screening}

PPB1 was screened for NRPS, PKS I, PKS II genes using primers $\mathrm{A} 3 \mathrm{~F}, \mathrm{A7R}, \mathrm{K} 1 \mathrm{~F}, \mathrm{M} 6 \mathrm{R}, \mathrm{KS}_{\alpha}$, and $\mathrm{KS}_{\beta}$ (Table 2). gDNA was isolated using the UltraClean microbial DNA isolation kit (Mo Bio) according to the provided protocol and quantified using NanoDrop ND-1000 spectrophotometer. PCR was set to the following parameters for touchdown: initialization at $95^{\circ} \mathrm{C}$ for $5 \mathrm{~min}, 10$ cycles of denaturation at $95^{\circ} \mathrm{C}$ for $30 \mathrm{~s}$, annealing at $60^{\circ} \mathrm{C}$ for $30 \mathrm{~s}$ with $2^{\circ}$ decrease each cycle, elongation at $72^{\circ} \mathrm{C}$ for $90 \mathrm{~s}$, followed by 30 cycles of denaturation at $95^{\circ} \mathrm{C}$ for $30 \mathrm{~s}$, annealing at $40^{\circ} \mathrm{C}$ for $30 \mathrm{~s}$, final extension at $72^{\circ} \mathrm{C}$ for $7 \mathrm{~min}$, and held at $4^{\circ} \mathrm{C}$ (Kennedy et al., 2008). PCR products were verified on a $1.5 \%$ agarose gel run at $80 \mathrm{~V}$ for $\sim 30-60 \mathrm{~min}$ and using Promega 100 bp ladder. P. aeruginosa was used as a positive control. E. coli and nuclease-free water served as negative controls.

\section{Pigment Extraction}

PPB1 liquid cultures were centrifuged at $523.5 \mathrm{rad} / \mathrm{s}$ for $10 \mathrm{~min}$ and the supernatant was discarded. The pelleted cells underwent EtOH extraction (Patil et al., 2011). The EtOH extract was then syringe-filtered $(0.2 \mu \mathrm{m}$ pore size $)$, dried, and stored until further application. 


\section{Disc Diffusion Assay}

Twenty-five $\mu \mathrm{L}$ of the following solutions were spotted onto sterile $6 \mathrm{~mm}$ diameter disks (Whatman) that were six filters thick: 10,000 $\mu \mathrm{g} / \mu \mathrm{L}$ PPB1 extract in dimethylsulfoxide (DMSO), DMSO, $400 \mu \mathrm{g} / \mu \mathrm{L}$ ampicillin in DMSO, and 400 $\mu \mathrm{g} / \mu \mathrm{L}$ kanamycin in DMSO. The DMSO disc served as a

TABLE 1 | Bacterial strains used in this antibacterial assay and TA cloning.

\begin{tabular}{|c|c|c|}
\hline Strain & Characteristics & References \\
\hline PPB1 & $\begin{array}{l}\text { Wild-type strain } \\
\text { Pseudoalteromonas sp. isolated } \\
\text { from Petrosia sp. }\end{array}$ & This study \\
\hline ATCC 14579 & $\begin{array}{l}\text { Non-virulent strain Bacillus } \\
\text { cereus }\end{array}$ & $\begin{array}{l}\text { Hayrapetyan et al., } \\
2015\end{array}$ \\
\hline ATCC 25923 & $\begin{array}{l}\text { Non-virulent strain } \\
\text { Staphylococcus aureus }\end{array}$ & Treangen et al., 2014 \\
\hline K12 & $\begin{array}{l}\text { Non-virulent strain Escherichia } \\
\text { coli }\end{array}$ & Bachmann, 1972 \\
\hline PB 4-1 (B1) & $\begin{array}{l}\text { Wild-type strain Pseudovibrio } \\
\text { denitrificans isolated from } \\
\text { Petrosia sp. }\end{array}$ & This study \\
\hline PB 4-1 (B2) & $\begin{array}{l}\text { Wild-type strain Photobacterium } \\
\text { rosenbergii isolated from } \\
\text { Petrosia sp. }\end{array}$ & This study \\
\hline PB 4-2 (B1) & $\begin{array}{l}\text { Wild-type strain Vibrio harveyi } \\
\text { isolated from Petrosia sp. }\end{array}$ & This study \\
\hline PB 4-2 (C2) & $\begin{array}{l}\text { Wild-type strain } \\
\text { Pseudoalteromonas arabiensis } \\
\text { isolated from Petrosia sp. }\end{array}$ & This study \\
\hline TOP10 & $\begin{array}{l}\text { Chemically competent } \\
\text { Escherichia coli F- mcrA } \\
\Delta(\text { mrr-hsd RMS-mcrBC) } \\
\Phi 80 / a c Z \Delta M 15 \Delta \text { lacX74 recA1 } \\
\text { araD139 } \Delta(\text { araleu }) 7697 \text { galU } \\
\text { galK rpsL (StrR) endA1 nupG }\end{array}$ & Chan et al., 2013 \\
\hline
\end{tabular}

negative control. The ampicillin and kanamycin disks served as positive controls.

B. cereus ATCC 14579, E. coli K12, and S. aureus ATCC 25923 were grown in $10 \mathrm{~mL} \mathrm{LB}$ broth, while $P$. arabiensis, $P$. denitrificans, $P$. rosenbergii, and $V$. harveyi were grown in $10 \mathrm{~mL}$ marine broth (Difco). All cultures were grown at $25{ }^{\circ} \mathrm{C}$ for $\sim 24 \mathrm{~h}$, shaking at $12.5 \mathrm{RPM}$. The final concentration of cells was $\sim 10^{6} \mathrm{CFU} / \mathrm{mL}$. Hundred $\mu \mathrm{L}$ lawn of each culture was spread on Mueller-Hinton agar-for B. cereus, E. coli, and S. aureusand MA-for $P$. arabiensis, $P$. denitrificans, $P$. rosenbergii, and $V$. harveyi. The plates were left to air dry in a laminar flow cabinet. Disks were aseptically placed onto the surface of the inoculated agar plate and incubated for $20 \mathrm{~h}$. at $37^{\circ} \mathrm{C}$ (Kennedy et al., 2009). Zones of inhibition were measured and recorded.

\section{Flow Cytometry}

S. aureus was inoculated in $10 \mathrm{~mL}$ nutrient broth $(\mathrm{NB})$ at $37^{\circ} \mathrm{C}$ for $\sim 12 \mathrm{~h}$ with shaking $(16.8 \mathrm{rad} / \mathrm{s})$. After $12 \mathrm{~h}$, triplicates of each $100 \mu \mathrm{L}$ treatment were placed in $5 \mathrm{~mL}$ NB inoculated with $50 \mu \mathrm{L}$ $S$. aureus. The negative controls were the untreated and DMSO treatment. The positive controls were the antibiotic treatments: $10 \mathrm{mg} / \mathrm{mL}$ ampicillin in DMSO (amp10) and $30 \mathrm{mg} / \mathrm{mL}$ chloramphenicol in DMSO (cam30). The sample treatments were $1,000 \mathrm{mg} / \mathrm{kg}$ PPB1 extract in DMSO, $750 \mathrm{mg} / \mathrm{kg}$ PPB1 extract in DMSO, and $500 \mathrm{mg} / \mathrm{kg}$ PPB1 extract in DMSO. The treatments in $S$. aureus were incubated at $37{ }^{\circ} \mathrm{C}$ for $\sim 12 \mathrm{~h}$ with shaking (160 RPM).

After $12 \mathrm{~h}, 1 \mathrm{~mL}$ of each treatment was incubated with 0.5 $\mu \mathrm{L}$ of $5 \mathrm{mmol} / \mathrm{L}$ SYTO BC green-fluorescent nucleic acid stain (Invitrogen) and $0.5 \mu \mathrm{L}$ of $1.5 \mathrm{mmol} / \mathrm{L}$ propidium iodide (PI) for $20 \mathrm{~min}$ at room temperature.

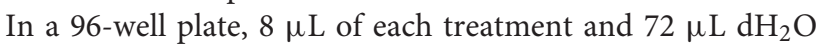
was aliquoted into each well, making a total of $80 \mu \mathrm{L}$. Each set of triplicates was separated by a well of $\mathrm{dH}_{2} \mathrm{O}$ to clean the flow cytometer in between samples.

TABLE 2 | Primer sequences.

\begin{tabular}{|c|c|c|c|}
\hline Primer & Sequence & Gene of Interest & References \\
\hline $27 \mathrm{~F}$ & 5'-AGAGTTTGATCMTGGCTCAG-3' & 16S rRNA & Lane, 1991 \\
\hline $1492 R$ & 5'-TACGGYTACCTTGTTACGACTT-3' & $16 \mathrm{~S}$ rRNA & Lane, 1991 \\
\hline A7R & 5'-SASGTCVCCSGTSCGGTAS-3' & $\begin{array}{l}\text { NRPS } \\
\text { Adenylation domain }\end{array}$ & $\begin{array}{l}\text { Ayuso-Sacido and Genilloud, } \\
2005\end{array}$ \\
\hline M6R & 5'-CGCAGGTTSCSGTACCAGTA-3' & $\begin{array}{l}\text { PKS-1 } \\
\text { Ketosynthase- } \\
\text { acyltransferase domains }\end{array}$ & $\begin{array}{l}\text { Ayuso-Sacido and Genilloud, } \\
2005\end{array}$ \\
\hline $\mathrm{KS}_{\alpha}$ & 5'-TSGCSTGCTTGGAYGCSATC-3' & $\begin{array}{l}\text { PKS-2 } \\
\text { Ketosynthase domain }\end{array}$ & Metsä-Ketel et al., 1999 \\
\hline
\end{tabular}


Flow cytometry was performed with a C6 Flow Cytometer (BD Accuri). The green fluorescence of the SYTO BC dye (FL1) was collected using a $533 \mathrm{~nm} \pm 30 \mathrm{~nm}$ optical filter; the red fluorescence of the PI dye (FL3) was collected using a $585 \mathrm{~nm} \pm$ $40 \mathrm{~nm}$ optical filter. SYTO BC (maximum at $500 \mathrm{~nm}$ ) is a nucleic acid stain for both gram-positive and gram-negative bacteria. PI (maximum at $617 \mathrm{~nm}$ ) uptake indicates ruptured cell membranes and cell death (Gunasekera et al., 2000; Ben-Amor et al., 2005).

Using the 96 deep well plate template, the flow rate was set at $14 \mu \mathrm{L} / \mathrm{min}$, the threshold was set at FSC-H $<10$, and run limits were set at $15 \mu \mathrm{L}$ for sample wells and $10 \mu \mathrm{L}$ for $\mathrm{dH}_{2} \mathrm{O}$ wells. During the run, there was one wash cycle per well and the plate was agitated for two cycles per well.

Sorting criteria were defined by drawing gates in a bivariate dot plot of FL3-H (PI red fluorescence height) vs. FL1-H (SYTO $\mathrm{BC}$ green fluorescence height). All parameters were measured using logarithmic amplification.

The total count and the number of counts in each quadrant for all samples were recorded. The adjusted total count was calculated by taking the difference between the total count and the count in the lower-left quadrant (Ben-Amor et al., 2005). The percentage of viable (upper-left quadrant), injured (upper-right quadrant), and dead (lower-right quadrant) cells was calculated with the adjusted total count. A triplicate average for the adjusted total count and the percentage of viable, injured, and dead cells per treatment. Statistical analysis of the viable, injured, and dead percentages before averaging were done with a one-way ANOVA and with Tukey's multiple comparisons.

\section{Ferric Reducing Antioxidant Power (FRAP) Assay}

The components of the FRAP reagent were 10:1:1 with $15 \mathrm{~mL}$ of $300 \mathrm{mmol} / \mathrm{L}$ acetate buffer ( $\mathrm{pH} \mathrm{3.6),} 1.5 \mathrm{~mL}$ of $10 \mathrm{mM} \mathrm{2,4,6-}$ tripyridyl-s-triazine (TPTZ) solution, and $1.5 \mathrm{~mL}$ of $20 \mathrm{mmol} / \mathrm{L}$ $\mathrm{FeCl}_{3} \cdot 6 \mathrm{H}_{2} \mathrm{O}$ (stored at $4^{\circ} \mathrm{C}$ ). Before use, the FRAP reagent was heated to $37^{\circ} \mathrm{C}$ for $30 \mathrm{~min}$. In a 96 -well plate, $150 \mu \mathrm{L}$ of working FRAP reagent was placed into wells and $150 \mu \mathrm{L}$ of $\mathrm{dH}_{2} \mathrm{O}$ were placed into separate wells and a blank reading at $595 \mathrm{~nm}$ was taken. Twenty $\mu \mathrm{L}$ of samples, positive control (ascorbic acid), negative control (EtOH), and standard (1,000 $\mu \mathrm{mol} / \mathrm{L} \mathrm{FeSO}_{4} \cdot 7 \mathrm{H}_{2} \mathrm{O}$ ) were added to the FRAP reagent wells in triplicates. Twenty $\mu \mathrm{L}$ of only the samples were added to the $\mathrm{dH}_{2} \mathrm{O}$ wells in triplicates. After $8 \mathrm{~min}$, a second reading at $595 \mathrm{~nm}$ was taken. FRAP values for each sample were determined by taking the difference of the final reading with their respective blank reading of the FRAP reagent and their respective averaged pigment reading. A two-sample T-test was performed between the PPB1 crude extract-treated and the untreated samples (Moon and Shibamoto, 2009).

\section{Genomic DNA Isolation, Library Preparation, and Genome Sequencing}

gDNA was isolated using the UltraClean microbial DNA isolation kit (Mo Bio) according to the provided protocol. Genome library was prepared using the New England Biolabs Fast DNA fragmentation and library prep set for Ion Torrent, selected to a target length of $480 \mathrm{bp}$. The Kapa Biosystems Ion Torrent library quantification kit and Agilent high sensitivity DNA kit were used to determine the library dilution factor and assess the library size distribution, respectively. Emulsion PCR was performed using the Ion PGM Hi-Q OT2 kit-400 on the Ion OneTouch 2 System. The percent templated Ion Sphere particles from unenriched samples was measured with the Ion Sphere quality control kit on the Qubit Fluorometer 3.0. Template enrichment was performed on the Ion OneTouch Enrichment System. The sample was loaded into an Ion 318 chip v2 and sequenced using the Ion PGM Hi-Q sequencing kit on the Ion PGM system (Sakai-Kawada et al., 2016).

\section{Genome Assembly and Annotation}

The data quality for the high throughput raw sequences was assessed using FASTQC. A De Bruijn graph assembly was performed using SPAdes assembler v. 3.5.0. The assembly quality was assessed using MUMmer, ABySS, and FRC. Genome annotation was performed using MAKER, PGAP, RAST, RNAmmer, and CRISPRfinder (Grissa et al., 2007; Lagesen et al., 2007; Aziz et al., 2008; Overbeek et al., 2014). Secondary metabolite gene clusters were characterized using antiSMASH - a bioinformatic tool for rapid genome-wide analysis of antibiotics and secondary metabolite biosynthesis, BAGEL4-a bioinformatic tool that mines for bacteriocins and bacterial RiPPs, NaPDoS, NP.searcher, and PRISM. The latter three are bioinformatic tools that rapidly detect NRPS and PKS domains (Altschul et al., 1990; Steinbeck et al., 2003; Li et al., 2009; Finn et al., 2011; Medema et al., 2011; Prlić et al., 2012; Ziemert et al., 2012; Blin et al., 2019).

\section{RESULTS}

\section{Physical Characterization and Identification of Pigment-Producing Bacteria}

Isolate PPB1 displayed a bright to deep red color on agar plates and within broth (Figure 2). Growth on agar began unpigmented and then red pigmentation developed as the colony grew over time. The bacterium grew within temperatures ranging from 18 to $27^{\circ} \mathrm{C}$. Electron microscopy revealed coccoid and short rods forms of PPB1 (Figure 2). 16S rRNA characterization revealed the closest neighbor as Pseudoalteromonas rubra strain SCSIO 6842 (Accession: CP013611.1) at 93\% identity (Figure 3).

\section{NRPS and PKS Screening and Antimicrobial Activity}

NRPS and PKS screening showed that PPB1 was positive for both NRPS and PKS genes. Upon initial screening for an antimicrobial activity via disc diffusion assay, PPB1 crude extract showed zones of inhibition against Gram-positive bacteria, $B$. cereus and $S$. aureus at $4.0 \mathrm{~mm} \pm 0.7 \mathrm{~mm}$ and $5.4 \mathrm{~mm} \pm$ $2.1 \mathrm{~mm}$ diameters, respectively. PPB1 crude extract did not show antimicrobial activity against Gram-negative bacterium, E. coli $(0.0 \mathrm{~mm})$ (Table 3). PPB1 also inhibited the growth of other marine bacteria from the Petrosia sponge tissue and included 


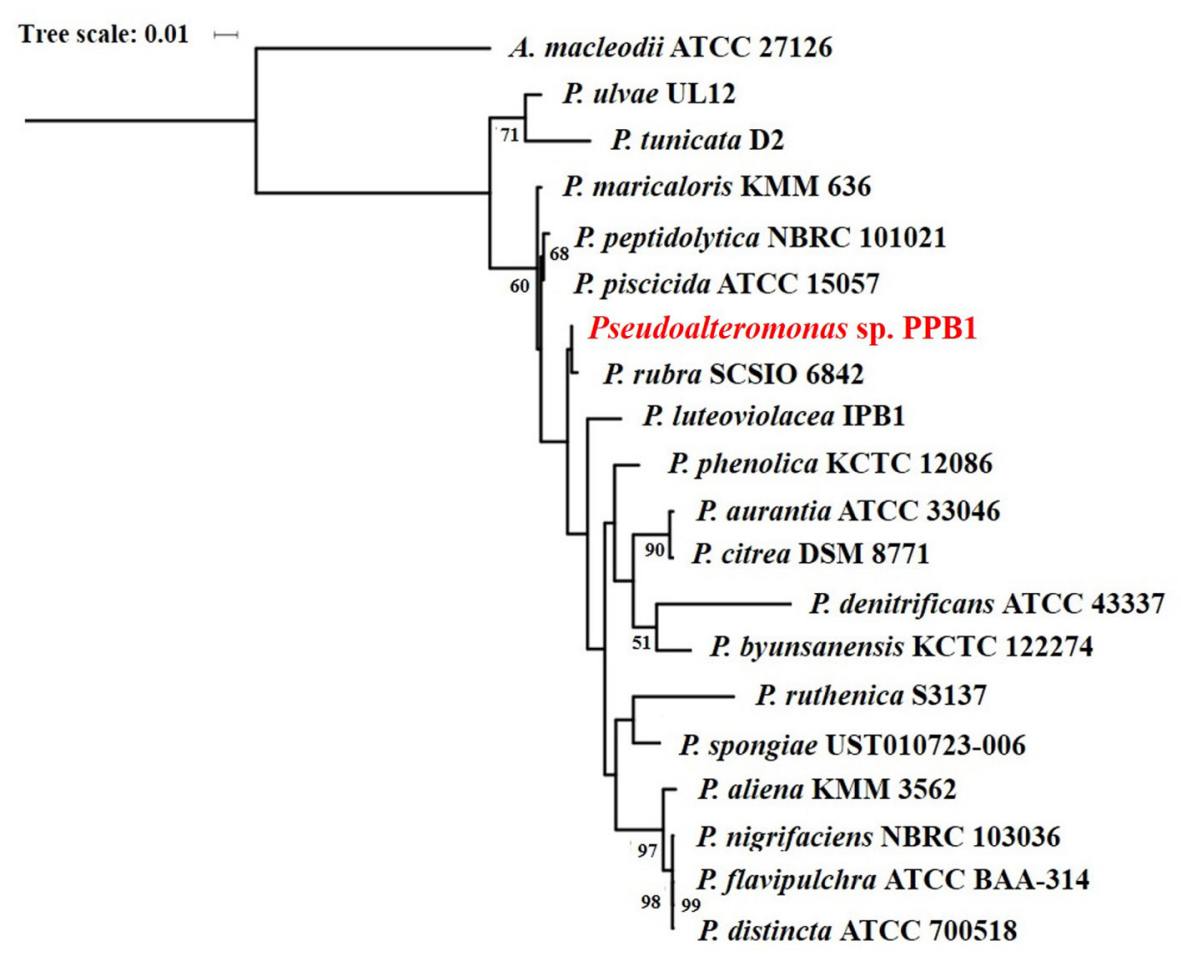

FIGURE 3 | Maximum likelihood phylogenetic tree of pigmented Pseudoalteromonas species based on 16S rRNA gene sequences.

TABLE 3 | Disc diffusion assay of PPB1 extract.

Test organism

Growth inhibition zone activity

PPB1 extract $(250 \mathrm{mg})$

Ampicillin

(10 mg)

Kanamycin

(10 mg)

\begin{tabular}{ll}
${\text { B. } \text { cereus }^{\mathrm{a}}}$ & $+(4.0 \mathrm{~mm} \pm 0.7 \mathrm{~mm})$ \\
E. coli $^{\mathrm{a}}$ & $-(0.0 \mathrm{~mm})$ \\
${\text { S. } \text { aureus }^{\mathrm{a}}}^{\text {P. rosenbergii }}$ & $+(5.4 \mathrm{~mm} \pm 2.1 \mathrm{~mm})$ \\
P. arabiensis $^{\mathrm{b}}$ & $+(1.1 \mathrm{~mm} \pm 0.5 \mathrm{~mm})$ \\
P. denitrificans & \\
V. harveyi $^{\mathrm{b}}$ & $+(1.0 \mathrm{~mm})$ \\
\hline
\end{tabular}

${ }^{a}$ Assay performed on Mueller-Hinton media.

${ }^{b}$ Assay performed on marine agar (Difco).

P. rosenbergii $(1.1 \mathrm{~mm} \pm 0.5 \mathrm{~mm})$ and $P$. arabiensis $(1.0 \mathrm{~mm})$. On the other hand, PPB1 demonstrated variable antimicrobial activity against $P$. denitrificans $(1.3 \mathrm{~mm} \pm 1.1 \mathrm{~mm})$ and $V$. harveyi $(0.8 \mathrm{~mm} \pm 0.4 \mathrm{~mm})$ (Table 3$)$.

Quantitative antimicrobial assays were conducted via flow cytometry to further investigate the effects of the crude extract on $S$. aureus (Figure 4A). The viability of $S$. aureus cells decreased from $67.8 \%$ to $25.2 \%$ when the concentration of the crude extract was increased from $0 \mathrm{mg} / \mathrm{kg}$ to $500 \mathrm{mg} / \mathrm{kg}$ (Table 4). However, there was no significant difference in response to crude extract treatments among viable (25.2-28.8\%), injured (69.4-72.7\%), and dead cells (1.4-2.1\%).

\section{Antioxidant Activity}

The FRAP assay analyzed the antioxidant potential of a test sample by measuring how readily it reduces ferric ions $\left(\mathrm{Fe}^{3+}\right)$ to ferrous ions $\left(\mathrm{Fe}^{2+}\right)$. As a result, the ferrous ions formed a complex with the $\mathrm{TPTZ}_{2}$ working reagent and produced blue coloration, which were measured and quantified. The PPB1 crude extract showed significant ferric reducing antioxidant potential $(1.395 \pm 0.123 ; p \leq 0.05)$ in comparison to the EtOH negative control $(0.004 \pm 0.001)$ (Table 5). This response was more than the $1 \mathrm{mmol} / \mathrm{L} \mathrm{FeSO}_{4} \bullet 7 \mathrm{H}_{2} \mathrm{O}$ standard $(1.052 \pm 0.056)$, which had iron present in the already reduced $\left(\mathrm{Fe}^{2+}\right)$ form, but less than ascorbic acid control (1.814 \pm 0.040$)$ (Figure 4B). 


\section{Genome Sequencing and Assembly}

Upon sequencing the genome, a total of 8,297,550 raw reads were produced. After accounting for enrichment, clonal amplification error, test fragments, adapter dimers, and other quality assessments, $68 \%$ of those reads remained usable, yielding a total of $5,632,815$ reads with an average read length of 307

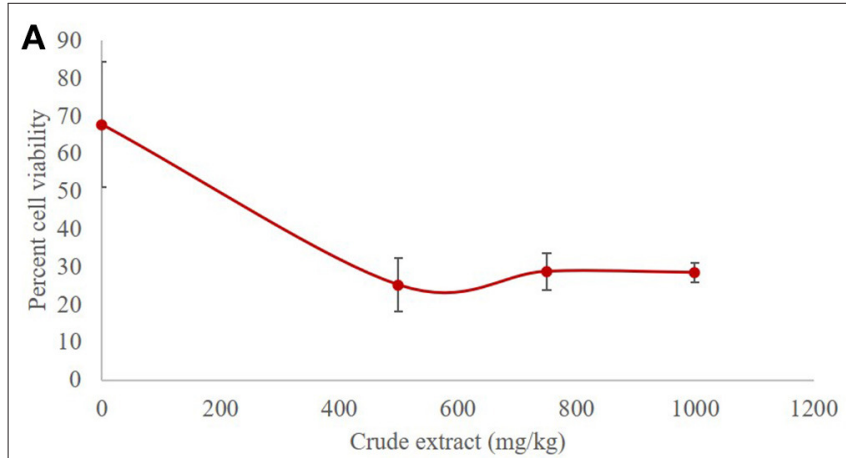

B

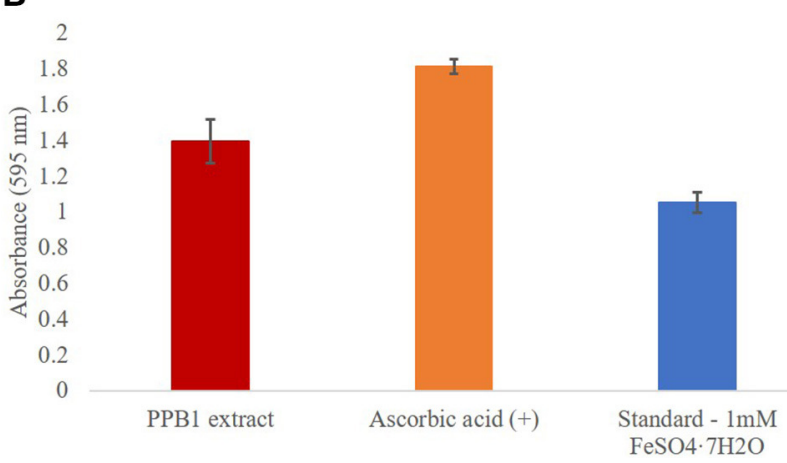

FIGURE 4 | (A) Antimicrobial activity of PPB1 crude extract against S. aureus. PPB1 crude extract demonstrated a significant decrease in cell viability at 500 $\mathrm{mg} / \mathrm{kg}(25.2 \pm 2.6), 750 \mathrm{mg} / \mathrm{kg}$ (28.8 \pm 4.8$)$, and $1,000 \mathrm{mg} / \mathrm{kg}$ (28.5 \pm 7.1$)$. Error bars represent the standard deviation of the samples. (B) Antioxidant activity of PPB1 crude extract via FRAP assay. The PPB1 crude extract demonstrated significant ferric-reducing potential $(1.395 \pm 0.123 ; p \leq 0.05)$ in comparison to the $\mathrm{EtOH}$ negative control $(0.004 \pm 0.001)$. Error bars represent the standard deviation of the samples. bp and a median read length of $345 \mathrm{bp}$, resulting in $1.73 \mathrm{~Gb}$ of sequenced data.

SPAdes assembled a genome containing 121 contigs with a total size of 5,915,516 bp (283-fold draft coverage), an $\mathrm{N}_{50}$ contig length of 192,396 nucleotides, and a mean GC-content of $47.4 \%$ (Table 6).

\section{Genome Mining and Annotation}

RAST predicted 5,201 gene-coding sequences with 2,082 features within the RAST subsystem. Of those subsystem features, 15 were characterized as bacteriocin and ribosomally-synthesized antibacterial peptides, and 16 were characterized as secondary metabolism (Table 6).

Upon analysis of secondary metabolism and natural product biosynthesis, several gene clusters and domains of interest were found. Analysis using antiSMASH resulted in 29 hits (Blin et al., 2019). NaPDoS returned 80 hits. Of those, 12 were KS-domains and 68 were C-domains. NP.searcher returned 11 hits, seven modular NRPSs, and three mixed modular NRPS/PKSs. PRISM, on the other hand, returned 10 hits, one PKS, 14 NRPS, and four NRPS/PKS clusters. Furthermore, BAGEL4 resulted in 4 hits belonging to bottromycin and lanthipeptide classes (Table 7).

The presence of a potential indigoidine pathway was particularly intriguing, since the bacterial isolate PPB1 did not express a blue or purple pigment on agar plates or in liquid media. The NRPS encoding indigoidine synthetase (indC) in Streptomyces chromofuscus showed a $40 \%$ sequence similarity with a region of the PPB1 genome on node 23 . On the other

TABLE 5 | Antioxidant activity of PPB1 crude extract via FRAP assay ( $n=3)$.

\begin{tabular}{lc}
\hline Treatment & $\begin{array}{c}\text { Average absorbance } \\
\text { at } 595 \mathbf{~ n m} \text { (Standarc } \\
\text { deviation) }\end{array}$ \\
\hline PPB1 extract & $1.395(0.123)$ \\
$\mathrm{EtOH}$ (negative control) & $0.004(0.001)$ \\
Ascorbic acid (positive control) & $1.814(0.040)$ \\
$1 \mathrm{mM} \mathrm{FeSO}_{4} \bullet 7 \mathrm{H}_{2} \mathrm{O}$ (standard) & $1.052(0.056)$
\end{tabular}

TABLE 4 | Average cell viability of $S$. aureus in various treatments $(n=3)$.

\begin{tabular}{|c|c|c|c|c|}
\hline \multirow[t]{2}{*}{ Treatment } & \multirow{2}{*}{$\begin{array}{l}\text { Average adjusted } \\
\text { total count }\end{array}$} & \multicolumn{3}{|c|}{ Average viability count (\%) } \\
\hline & & $\begin{array}{c}\text { Viable } \\
\text { cells (SD) }\end{array}$ & $\begin{array}{l}\text { Injured } \\
\text { cells (SD) }\end{array}$ & $\begin{array}{c}\text { Dead cells } \\
\text { (SD) }\end{array}$ \\
\hline No treatment & $2.65 \times 10^{4}$ & $30.4(1.9)$ & $69.5(1.9)$ & $0.1(0.01)$ \\
\hline amp10 & $1.30 \times 10^{3}$ & $13.8(1.5)$ & $81.0(2.0)$ & $5.3(0.7)$ \\
\hline cam30 & $1.42 \times 10^{3}$ & $16.0(8.4)$ & $79.0(8.0)$ & $5.0(0.5)$ \\
\hline 0 mg/kg ext. & $4.24 \times 10^{4}$ & $67.8(16.6)$ & $32.0(16.9)$ & $0.1(0.1)$ \\
\hline 500 mg/kg ext. & $4.80 \times 10^{4}$ & $25.2(2.6)$ & $72.7(2.7)$ & $2.1(0.2)$ \\
\hline 750 mg/kg ext. & $4.40 \times 10^{4}$ & $28.8(4.8)$ & $69.8(5.2)$ & $1.4(0.8)$ \\
\hline 1,000 mg/kg ext. & $3.09 \times 10^{4}$ & $28.5(7.1)$ & $69.4(7.2)$ & $2.1(0.2)$ \\
\hline
\end{tabular}


TABLE 6 | Nucleotide and gene count levels of the genome of Pseudoalteromonas sp. PPB1.

\begin{tabular}{lc}
\hline Attribute & Value \\
\hline Genome size (bp) & $5,915,516$ \\
DNA G + C (\%) & 47.4 \\
DNA contigs & 121 \\
N $_{50}(\mathrm{bp})$ & 192,396 \\
L $_{50}(\mathrm{bp})$ & 11 \\
Draft coverage & 283 \\
Total predicted genes & 5,201 \\
Number of RNAs & 109 \\
rRNA operon count & 12 \\
Genes in subsystem features & 2,082 \\
CRISPR count & 9 \\
\hline
\end{tabular}

TABLE 7 | Secondary metabolite gene clusters via various bioinformatic tools.

\begin{tabular}{|c|c|c|}
\hline Tool & Hits & Class \\
\hline antiSMASH & 29 & $\begin{array}{l}\text { amonabactin P750, kalimantacin A, } \\
\text { indigoidine, rhizomide A-C, NRPS, } \\
\text { NRPS-like, T1PKS, T3PKS, } \\
\text { transAT-PKS, bacteriocin, } \\
\text { lanthipeptide, hserlactone }\end{array}$ \\
\hline BAGEL4 & 4 & $\begin{array}{l}\text { bottromycin; lanthipeptide class I; } \\
\text { lanthipeptide class IV }\end{array}$ \\
\hline NaPDoS & 80 & $\begin{array}{l}12 \text { ketoacyl synthase domains; } 68 \\
\text { condensation domains }\end{array}$ \\
\hline NP.searcher & 11 & $\begin{array}{l}\text { Seven modular NRPSs; three mixed } \\
\text { modular NRPS/PKSs; } 1 \\
\text { non-mevalonate terpenoid (mep) } \\
\text { genes }\end{array}$ \\
\hline PRISM & 10 & $\begin{array}{l}1 \text { polyketide cluster; } 14 \\
\text { non-ribosomal peptide clusters; } 4 \\
\text { non-ribosomal peptide/polyketide } \\
\text { clusters }\end{array}$ \\
\hline
\end{tabular}

hand, the marine sponge host, Petrosia had an observed redpurple coloration. It is inferred that the reddish hue is caused by the abundance of prodiginine within PPB1; however, no other pigmented microorganism was isolated from the sponge tissue.

\section{PPB1 Genome Contains a Prodiginine Biosynthetic Gene Cluster and Monooxygenase-Like Enzyme}

Genome mining and annotation characterized the presence of a prodigiosin biosynthetic gene cluster and verified the presence of prodigiosin and its analogs. This study also observed the heterogeneity of the gene cluster across various prodiginineproducing species and genera (Table 8, Figure 5). Thirteen open reading frames (ORFs) on node $3(204,016-224,268)$ in PPB1 were aligned against the pig gene cluster in $P$. denitrificans, $P$. rubra, and $S$. marcescens and the red gene cluster in $S$. coelicolor.

$P$. denitrificans, $P$. rubra, and $S$. marcescens shared both the MAP and MBC biosynthetic pathway with PPB1. Out of those three species, the pig gene cluster from $P$. rubra aligned the closest. The percent identity of each ORF ranged from 88.58 to $97.18 \%$ with a mean and median of 93.61 and 94.30\%, respectively. Three of those ORFs (ORF 2, ORF 4, ORF5) aligned with the MAP biosynthetic pathway ranging from 91.21 to $95.34 \%$ with a mean of $93.79 \%$ and a median of 94.83\%. Nine ORFs (ORF1, ORF6-13) aligned with the MBP biosynthetic pathway ranging from 88.58 to $97.18 \%$ with a mean of $93.61 \%$ and a median of $94.30 \%$. One ORF aligned with a gene responsible for terminal condensation of MAP and $\mathrm{MBC}$ to form prodigiosin and had a percent identity of 93.09\%. The pig pathways in P. denitrificans and S. marcescens aligned loosely with the ORFs in PPB1. When PPB1 was aligned with $S$. marcescens, the percent identity of each ORF ranged from $47.83 \%$ to $73.33 \%$ with a mean and median of 63.59 and $64.52 \%$, respectively. Interestingly, when PPB1 was aligned with $P$. denitrificans, there was a slightly lower percent identity ranging from 45.39 to $62.25 \%$ with a mean of $54.58 \%$ and a median of $54.29 \%$.

Meanwhile, $S$. coelicolor shared only the MBC biosynthetic pathway and the gene responsible for terminal condensation with $\mathrm{PPB} 1$; however, there was high heterogeneity ranging from 17.19 to $48.82 \%$ with a mean and median of 33.44 and $31.44 \%$, respectively.

In addition, ORF14, on node $13(46,438-47,706)$ closely aligned to a putative oxidase with PRUB680 in $P$. rubra at $95.27 \%$ and loosely aligned with redG in $P$. denitrificans and S. coelicolor at 42.65 and $43.44 \%$, respectively (Table 8, Figure 5). red $G$ is a Rieske oxygenase responsible for cyclization of undecylprodigiosin to form streptorubin B (Salem et al., 2014). ORF14 and redG were also homologous to a putative oxidase $(\operatorname{tam} C)$ in $P$. tunicata, which was known to facilitate the cyclization of tambjamine YP1 (Burke et al., 2007). This may explain the formation of cycloprodigiosin and other cyclic prodiginine analogs in the PPB1 strain.

\section{DISCUSSION}

PPB1 demonstrated potential of biological activities including antibacterial and antioxidant activity. The data suggests that the PPB1 crude extract targets structures within Gram-positive bacteria. Previous studies have shown that prodigiosin and its various derivatives demonstrated antimicrobial activity against a wide-range of terrestrial bacterial species (Sakai-Kawada et al., 2019). In this study, $250 \mathrm{mg}$ of a crude extract was used to observe the holistic effects of PPB1 against various bacterial species. Although the concentration of the crude extract in this study was higher than in previous studies, the zones of inhibition against species such as $B$. cereus, $E$. coli, and $S$. aureus were notably narrower (Ramesh et al., 2019a). This study expanded those tests to several marine isolates to understand how PPB1 interacts within its marine environment such as $P$. rosenbergii, $P$. arabiensis, $P$. denitrificans, and $V$. harveyi. Testing revealed that PPB1 had variable bioactivity against several other species of bacteria harboring within the Petrosia marine sponge, which may suggest PPB1 was competing for space and resources within 
TABLE 8 | Annotated prodiginine biosynthetic gene cluster and their associated homologs.

\begin{tabular}{|c|c|c|c|c|c|c|c|c|c|}
\hline \multirow[t]{2}{*}{ ORFs (PPB1) } & \multirow[t]{2}{*}{ Predicted gene function } & \multicolumn{2}{|c|}{ P. denitrificans } & \multicolumn{2}{|c|}{ P. rubra } & \multicolumn{2}{|c|}{ S. marcescens } & \multicolumn{2}{|c|}{ S. coelicolor } \\
\hline & & $\begin{array}{l}\text { pig } \\
\text { genes }\end{array}$ & $\begin{array}{l}\text { Percent } \\
\text { identity }\end{array}$ & $\begin{array}{l}\text { pig } \\
\text { genes }\end{array}$ & $\begin{array}{l}\text { Percent } \\
\text { identity }\end{array}$ & $\begin{array}{l}\text { pig } \\
\text { genes }\end{array}$ & $\begin{array}{l}\text { Percent } \\
\text { identity }\end{array}$ & $\begin{array}{l}\text { red } \\
\text { genes }\end{array}$ & $\begin{array}{l}\text { Percent } \\
\text { identity }\end{array}$ \\
\hline ORF1 & $\begin{array}{l}\text { L-prolyl-PCP } \\
\text { dehydrogenase (MBC) }\end{array}$ & pigA & 59.22 & pigA & 94.55 & pigA & 65.63 & redW & 43.57 \\
\hline ORF2 & $\begin{array}{l}\mathrm{H}_{2} \mathrm{MAP} \\
\text { oxidase/dehydrogenase } \\
\text { (MAP) }\end{array}$ & pigB & 51.46 & pigB & 91.21 & pigB & 61.58 & - & - \\
\hline ORF3 & $\begin{array}{l}\text { Terminal condensing } \\
\text { enzyme }\end{array}$ & pigC & 58.07 & pigC & 93.09 & pigC & 67.99 & redH & 39.14 \\
\hline ORF4 & $\begin{array}{l}\text { 3-acetyloctanal synthase } \\
\text { (MAP) }\end{array}$ & pigD & 58.58 & pigD & 95.34 & pigD & 68.90 & - & - \\
\hline ORF5 & $\begin{array}{l}\text { Putative class III } \\
\text { aminotransferase (MAP) }\end{array}$ & pige & 60.76 & pigE & 94.83 & pigE & 71.80 & - & - \\
\hline ORF6 & $\begin{array}{l}\text { HBC O-methyl transferase } \\
(\mathrm{MBC})\end{array}$ & pigF & 62.25 & pigF & 95.98 & pigF & 73.33 & redl & 21.81 \\
\hline ORF7 & $\begin{array}{l}\text { Peptidyl carrier protein } \\
\text { (MBC) }\end{array}$ & pigG & 54.03 & pigG & 97.18 & pigG & 64.52 & redO & 17.19 \\
\hline ORF8 & $\begin{array}{l}\text { HBM synthetase (seryl } \\
\text { transferase) (MBC) }\end{array}$ & pigH & 58.47 & pigh & 94.30 & pigH & 67.55 & redN & 48.82 \\
\hline ORF9 & L-prolyl-AMP ligase (MBC) & pigl & 50.31 & pigl & 94.26 & pigl & 58.44 & redM & 38.70 \\
\hline ORF10 & $\begin{array}{l}\text { Pyrrolyl- } \beta \text {-ketoacyl ACP } \\
\text { synthase (MBC) }\end{array}$ & pigJ & 49.16 & pigJ & 92.19 & pigJ & 60.53 & redX & 31.44 \\
\hline ORF11 & Hypothetical protein (MBC) & pigK & 54.29 & pigk & 96.19 & pigk & 64.44 & redY & 46.15 \\
\hline ORF12 & $\begin{array}{l}\text { Phosphopantetheinyl } \\
\text { transferase (MBC) }\end{array}$ & pigL & 45.39 & pigL & 89.24 & pigL & 47.83 & redU & 22.84 \\
\hline ORF13 & HBC dehydrogenase (MBC) & pigM & 47.60 & pigM & 88.58 & pigM & 54.07 & redV & 30.47 \\
\hline ORF14 ${ }^{\mathrm{a}}$ & Putative oxidase & $\begin{array}{l}\text { redG- } \\
\text { like }\end{array}$ & 42.65 & $\begin{array}{l}\text { PRUB } \\
680\end{array}$ & 95.27 & - & - & redG & 43.44 \\
\hline
\end{tabular}

a denotes outside of prodiginine biosynthetic gene cluster, but directly involved in prodiginine biosynthesis.

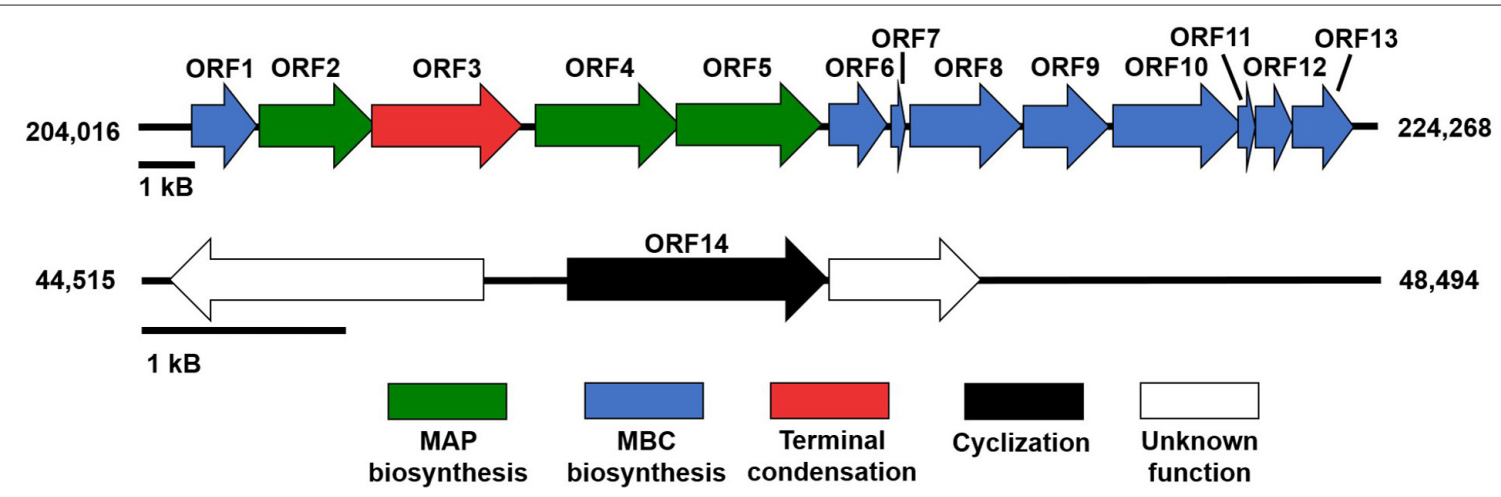

FIGURE 5 | Prodiginine biosynthetic gene cluster composed of MAP pathway (green), MBC pathway (blue), and terminal condensation (red). Gene involved with cyclization (black) was located outside of prodiginine biosynthetic gene cluster, but was directly involved in prodiginine biosynthesis.

its host. To obtain more comparable results with previous studies a bioassay-directed chemical purification may be performed to isolate the pigmented compounds and test their antibacterial properties separately.

Algal blooms frequently occur within coral reef systems (Schupp et al., 1999; Kim et al., 2008). The resulting ROS byproducts can cause oxidative stress via oxidation of lipid molecules and nucleic acids within the cell and ultimately lead to damaging effects on marine sponge tissue. Prior prodiginine studies suggested that the pigment stimulated the production and affected the influx of ROS (Danevči et al., 2016; Kimyon et al., 2016; Zhang et al., 2017). Sajjad et al. (2018) performed 
2,2-diphenyl-1-picrylhydrazyl radical (DPPH) assay followed by a lipid peroxidation inhibition assay using prodigiosin extracted from Streptomyces and obtained comparable results. Antioxidant activity along with previously recorded algicidal activity could help mitigate harmful algal blooms and provide much-needed protection for the Petrosia species.

Without a sponge tissue cell line, there is no way to observe the direct interaction between the host sponge and harboring bacteria. Beyond testing the various prodiginine analogs and other metabolites, a proper sponge tissue cell line must be created to accurately assess the effect of PPB1 and its secondary metabolites on Petrosia.

The characterization of a prodiginine biosynthetic gene cluster and the monooxygenase-like enzyme involved in cyclization confirms the presence of prodiginine pigments in PPB1. Although the gene cluster was annotated, various prodiginine analogs may still be synthesized in PPB1. ORF14 was annotated on a separate node over $150 \mathrm{kB}$ away from the rest of the biosynthetic gene cluster. Other genes involved in prodiginine analog biosynthesis may be found distant from the primary prodiginine biosynthetic gene cluster. Other than cycloprodigiosin, the genes for prodiginine analog biosynthesis have yet to be determined, which makes finding additional genes a difficult task (de Rond et al., 2017).

de Rond et al. (2017) and Kimata et al. (2017) demonstrated a directed approach by analyzing prodigiosin-like compounds (e.g., roseophilin and streptorubin B) and their respective pathways (e.g., rph and red pathways). This was followed by mining for homologous genes within their species of interest. Although the gene of interest (PRUB680) showed low sequence similarity with the $r p h$ and red genes, it demonstrated a similar function and was characterized as the gene responsible for the cyclization of prodigiosin.

The prodiginine biosynthetic pathway characterized in PPB1 already showed high heterogeneity between itself and other species such as P. denitrificans, S. marcescens, and S. coelicolor. Although the genes diverged between genera, their overall function remained the same (Williamson et al., 2006). P. rubra showed the closest association with the PPB1 isolate; however, there was still some variability within the gene cluster.

Petrosia had an observed red-purple coloration. One notable peptide-based metabolite that was mined from the genome was indigoidine, a bipyridyl deep blue-purple pigmented metabolite (Ramesh et al., 2019a). This pigment has been found in many different genera of bacteria and its biosynthesis was described in Streptomyces. Indigoidine biosynthesis is facilitated by a multimodule NRPS initiated by L-glutamate synthetase $(g \ln A)$, which is driven by ATP and utilizes L-glutamate and ammonia to form L-glutamine, followed by indigoidine synthetase (indC), which facilitates the condensation and cyclization of two glutamine molecules to synthesize indigoidine (Xu et al., 2015). However, the pigment was not observed within the cultured samples. Two possible explanations for this could be: (i) the presence of a recalcitrant pigment-producing microorganism that is unable or extremely difficult to grow in the laboratory setting or (ii) PPB1 is unable to produce the pigment at the same abundance under laboratory conditions. It is possible that indigoidine was produced, but only at low amounts. Furthermore, prodiginine was produced at high levels and thus could mask the expression of indigoidine. Rather than compete with the expression of prodiginine in PPB1, heterologous expression of the proposed indigoidine gene cluster from PPB1 into an unpigmented, manageable, and manipulatable microorganism like E. coli would confirm the presence and function of the pathway.

It is of note that mining looks only at the sequence similarity, but molecular manipulation and proper metabolomics are needed to confirm the presence of these bioactive compounds and their secondary metabolite gene clusters. Also, genome mining presents only previously discovered gene clusters but does not report any novel gene sets. Further molecular analysis is required to find unique gene sets that may be specific to a species or strain.

\section{CONCLUSION}

The production of bioactive secondary metabolites within hostassociated microorganisms suggests their role in providing environmental adaptation for its host. This study highlighted the antibacterial activity of PPB1 crude extract toward marine bacterial species, suggesting a competitive and protective role this microorganism has within its host environment. In addition, the antibacterial activity of PPB1 crude extract toward common terrestrial bacterial pathogens emphasized the potential that bioactive pigments have as future natural pharmaceuticals. The antioxidant activity of PPB1 crude extract also suggests that microorganisms can mitigate the harmful effects of ROS produced in marine ecosystems. Further studies need to be done in order to fully understand the complex relationship between host sponge and microorganisms and how they interact through secondary metabolites; further understanding of bioactive pigments, in turn, can allow us to develop natural products for various biotechnological applications to replace potentially harmful synthetic compounds with those that are safer to consume.

\section{NIST DISCLAIMER}

Certain commercial equipment, instruments, or materials are identified in this paper in order to specify the experimental procedure adequately. Such identification is not intended to imply recommendation or endorsement by NIST, nor is it intended to imply that the materials or equipment identified are necessarily the best available for the purpose.

\section{DATA AVAILABILITY STATEMENT}

The annotated draft genome sequence was deposited in DDBJ/EMBL/GenBank under accession no. JACEQV000000000. The version described in this paper is version JACEQV000000000.1. 


\section{AUTHOR CONTRIBUTIONS}

FS-K wrote the first draft and conducted experiments involved the identification of microbe, antimicrobial and antioxidant assays, genome sequencing, mining, and annotation. CI conducted antimicrobial assays (disc diffusion, flow cytometry), antioxidant assay, and genome sequencing. $\mathrm{KH}$ was involved in sampling of sponge, isolation of microbe, and antioxidant assay. C-JY was involved in genome sequencing, assembly, and submission. H-YN was involved in microbial isolation, electron microscopy, antimicrobial assay (disc diffusion), NRPS and PKS screening. MH conducted genome assembly and assembled the phylogenetic tree. EA was involved in genome assembly and submission. JA was the project advisor and facilitated all experiments performed in this study. All authors contributed

\section{REFERENCES}

Aerts, L. A. M. (2000). Dynamics behind standoff interactions in three reef sponge species and the coral Montastraea cavernosa. Mar. Ecol. 21, 191-204. doi: 10.1046/j.1439-0485.2000.00685.x

Alino, P. M., Sammarco, P. W., and Coll, J. C. (1992). Competitive strategies in soft corals (Coelenterata, Octocorallia). IV. Environmentally induced reversals in competitive superiority. Mar. Ecol. Prog. Ser. 81, 129-145. Available at: http:// www.jstor.org/stable/24827313

Altschul, S. F., Gish, W., Miller, W., Meyers, E. W., and Lipman, D. J. (1990). Basic local alignment search tool. J. Mol. Biol. 215, 403-410. doi: 10.1006/jmbi.1990.9999

Angermeier, H., Kamke, J., Abdelmohsen, U. R., Krohne, G., Pawlik, J. R., Lindquist, N. L., et al. (2011). The pathology of sponge orange band disease affecting the Caribbean barrel sponge Xestospongia muta. FEMS Microbiol. Ecol. 75, 218-230. doi: 10.1111/j.1574-6941.2010.01001.x

Ayling, A. M. (1981). The role of biological disturbance in temperate subtidal encrusting communities. Ecology 62, 830-847.

Ayuso-Sacido, A., and Genilloud, O. (2005). New PCR primers for the screening of NRPS and PKS-I systems in actinomycetes: detection and distribution of these biosynthetic gene sequences in major taxonomic groups. Microb. Ecol. 49, 10-24. doi: 10.1007/s00248-004-0249-6

Aziz, R. K., Bartels, D., Best, A. A., DeJongh, M., Disz, T., Edwards, R. A., et al. (2008). The RAST server: rapid annotations using subsystems technology. BMC Genomics 9:75. doi: 10.1186/1471-2164-9-75

Bachmann, B. J. (1972). Pedigrees of some mutant strains of Escherichia coli K-12. 36, 525-557.

Bandaranayake, W. M. (2006). The nature and role of pigments of marine invertebrates. Nat. Prod. Rep. 23, 223-255. doi: 10.1039/b307612c

Ben-Amor, K., Heilig, H., Smidt, H., Vaughan, E. E., Abee, T., and de Vos, W. M. (2005). Genetic diversity of viable, injured, and dead fecal bacteria assessed by fluorescence-activated cell sorting and 16S rRNA gene analysis. Appl. Environ. Microbiol. 71, 4679-4689. doi: 10.1128/AEM.71. 8.4679

Blin, K., Shaw, S., Steinke, K., Villebro, R., Ziemert, N., Lee, S. Y., et al. (2019). AntiSMASH 5.0: Updates to the secondary metabolite genome mining pipeline. Nucleic Acids Res. 47, W81-W87. doi: 10.1093/nar/gkz310

Bowman, J. P. (2007). Bioactive compound synthetic capacity and ecological significance of marine bacterial genus Pseudoalteromonas. Mar. Drugs 5, 220-241. doi: 10.3390/md20070017

Bramhachari, P. V., Ehrlich, H., and Pallela, R. (2016). "Introduction to the global scenario of marine sponge research," in Marine Sponges: Chemicobiological and Biomedical Applications, eds R. Pallela and H. Ehrlich (New Delhi: Springer). doi: 10.1007/978-81-322-2794-6_1

Burke, C., Thomas, T., Egan, S., and Kjelleberg, S. (2007). The use of functional genomics for the identification of a gene cluster encoding for the biosynthesis of an antifungal tambjamine in the marine bacterium to revision, read, and approved the submitted version of the manuscript.

\section{FUNDING}

This research was supported by the United States National Science Foundation grant HRD 0833211.

\section{ACKNOWLEDGMENTS}

We would like to acknowledge Mary Kay Harper from the University of Utah, who identified the genus of the sponge sample, Anthony D. Wright, who provided insight on the FRAP assay, and UH Hilo Evolutionary Genomics Core Facility.

Pseudoalteromonas tunicata: brief report. Environ. Microbiol. 9, 814-818. doi: 10.1111/j.1462-2920.2006.01177.x

Carballo, J. L., and Bell, J. (2017). Climate Change and Sponges: An Introduction. doi: 10.1007/978-3-319-59008-0_1

Chan, W. T., Verma, C. S., Lane, D. P., and Gan, S. K. E. (2013). A comparison and optimization of methods and factors affecting the transformation of Escherichia coli. Biosci. Rep. 33. doi: 10.1042/BSR20130098

Danevči,č, T., Vezjak, M. B., Tabor, M., Zorec, M., and Stopar, D. (2016). Prodigiosin induces autolysins in actively grown Bacillus subtilis cells. Front. Microbiol. 7, 1-10. doi: 10.3389/fmicb.2016.00027

de Oliveira, B. F. R., Freitas-Silva, J., Sánchez-Robinet, C., and Laport, M. S. (2020). Transmission of the sponge microbiome: moving towards a unified model. Environ. Microbiol. Rep. 12, 619-638. doi: 10.1111/1758-2229.12896

de Rond, T., Stow, P., Eigl, I., Johnson, R. E., Chan, L. J. G., Goyal, G., et al. (2017). Oxidative cyclization of prodigiosin by an alkylglycerol monooxygenase-like enzyme. Nat. Chem. Biol. 13, 1155-1159. doi: 10.1038/nchembio.2471

Diaz, M. C., and Rützler, K. (2001). Sponges: an essential component of Caribbean coral reefs. Bull. Mar. Sci. 69, 535-546.

Dunlap, M., and Pawlik, J. (1996). Video-monitored predation by Caribbean reef fishes on an array of mangrove and reef sponges. Int. J. Life Ocean. Coast. Waters 126, 117-123. doi: 10.1007/BF00571383

Finn, R. D., Clements, J., and Eddy, S. R. (2011). HMMER web server: interactive sequence similarity searching. Nucleic Acids Res. 39, W29-W37. doi: 10.1093/nar/gkr367

Goldberg, W. M. (2013). "Reef sponges," in The Biology of Reefs and Reef Organisms, eds. C. Henry and M. Corrado (Chicago: The University of Chicago Press), 79-101

Green, M. R., and Sambrook, J. (2019). Screening bacterial colonies using X-Gal and IPTG: $\alpha$-complementation. Cold Spring Harb. Protoc. 2019. doi: $10.1101 /$ pdb.prot101329

Grissa, I., Vergnaud, G., and Pourcel, C. (2007). CRISPRFinder: a web tool to identify clustered regularly interspaced short palindromic repeats. Nucleic Acids Res. 35, 52-57. doi: 10.1093/nar/gkm360

Gunasekera, T. S., Attfield, P. V., and Veal, D. A. (2000). A flow cytometry method for rapid detection and enumeration of fungal spores in the atmosphere. Appl. Environ. Microbiol. 66, 1228-1232. doi: 10.1128/AEM.66.3.1228-1232.2000

Hayrapetyan, H., Tempelaars, M., Groot, M. N., and Abee, T. (2015). Bacillus cereus ATCC 14579 RpoN (Sigma 54) is a pleiotropic regulator of growth, carbohydrate metabolism, motility, biofilm formation and toxin production. PLoS ONE 10, 1-19. doi: 10.1371/journal.pone.0134872

Hentschel, U., Hopke, J., Horn, M., Friedrich, A. B., Wagner, M., Hacker, J., et al. (2002). Molecular evidence for a uniform microbial community in sponges from different oceans molecular evidence for a uniform microbial community in sponges from different oceans. Appl. Environ. Microbiol. 68, 4431-4440. doi: 10.1128/AEM.68.9.4431

Hernández-Almanza, A., Muñiz-Márquez, D. B., de La Rosa, O., Navarro, V., Martínez-Medina, G., Rodríguez-Herrera, R., et al. 
(2017). Chapter 4 - Microbial Production of Bioactive Pigments, Oligosaccharides, and Peptides. Elsevier Inc. doi: 10.1016/B978-0-12-811372-1. 00004-X

Kennedy, J., Baker, P., Piper, C., Cotter, P. D., Walsh, M., Mooij, M. J., et al. (2009). Isolation and analysis of bacteria with antimicrobial activities from the marine sponge Haliclona simulans collected from Irish waters. Mar. Biotechnol. 11, 384-396. doi: 10.1007/s10126-008-9154-1

Kennedy, J., Codling, C. E., Jones, B. V., Dobson, A. D. W., and Marchesi, J. R. (2008). Diversity of microbes associated with the marine sponge, Haliclona simulans, isolated from Irish waters and identification of polyketide synthase genes from the sponge metagenome. Environ. Microbiol. 10, 1888-1902. doi: 10.1111/j.1462-2920.2008.01614.x

Kim, D., Kim, J. F., Yim, J. H., Kwon, S. K., Lee, C. H., and Lee, H. K. (2008). Red to red - the marine bacterium Hahella chejuensis and its product prodigiosin for mitigation of harmful algal blooms. J. Microbiol. Biotechnol. 18, 1621-1629.

Kimata, S., Izawa, M., Kawasaki, T., and Hayakawa, Y. (2017). Identification of a prodigiosin cyclization gene in the roseophilin producer and production of a new cyclized prodigiosin in a heterologous host. J. Antibiot. (Tokyo). 70, 196-199. doi: 10.1038/ja.2016.94

Kimyon, Ö., Das, T., Ibugo, A. I., Kutty, S. K., Ho, K. K., Tebben, J., et al. (2016). Serratia secondary metabolite prodigiosin inhibits Pseudomonas aeruginosa biofilm development by producing reactive oxygen species that damage biological molecules. Front. Microbiol. 7, 1-15. doi: 10.3389/fmicb.2016. 00972

Lagesen, K., Hallin, P., Rødland, E. A., Stærfeldt, H. H., Rognes, T., and Ussery, D. W. (2007). RNAmmer: consistent and rapid annotation of ribosomal RNA genes. Nucleic Acids Res. 35, 3100-3108. doi: 10.1093/nar/gkm160

Lane, D. J. (1991). "Nucleic acid techniques in bacterial systematics," in 16S/23S rRNA Sequencing, eds. E. Stackebrandt and M. Goodfellow (New York, NY: Wiley), 115-175.

Leong, H. Y., Show, P. L., Lim, M. H., Ooi, C. W., and Ling, T. C. (2018). Natural red pigments from plants and their health benefits: a review. Food Rev. Int. 34, 463-482. doi: 10.1080/87559129.2017.1326935

Li, M. H. T., Ung, P. M. U., Zajkowski, J., Garneau-Tsodikova, S., and Sherman, D. H. (2009). Automated genome mining for natural products. BMC Bioinformatics 10, 1-10. doi: 10.1186/1471-2105-10-185

Maldonado, M., Carmona, M. C., Velásquez, Z., Puig, A., Cruzado, A., López, A., et al. (2005). Siliceous sponges as a silicon sink: an overlooked aspect of benthopelagic coupling in the marine silicon cycle. Limnol. Oceanogr. 50, 799-809. doi: 10.4319/lo.2005.50.3.0799

Medema, M. H., Blin, K., Cimermancic, P., de Jager, V. C. L., Zakrzewski, P., Fischbach, M. A., et al. (2011). antiSMASH: rapid identification, annotation and analysis of secondary metabolite biosynthesis gene clusters in bacterial and fungal genome sequences. Nucleic Acids Res. 39, W339-46. doi: $10.1093 /$ nar/gkr466

Metsä-Ketel,ä, M., Salo, V., Halo, L., Hautala, A., Hakala, J., Mäntsäl,ä, P., et al. (1999). An efficient approach for screening minimal PKS genes from Streptomyces. FEMS Microbiol. Lett. 180, 1-6. doi: 10.1111/j.1574-6968.1999.tb08770.x

Moon, J. K., and Shibamoto, T. (2009). Antioxidant assays for plant and food components. J. Agric. Food Chem. 57, 1655-1666. doi: 10.1021/jf803537k

Overbeek, R., Olson, R., Pusch, G. D., Olsen, G. J., Davis, J. J., Disz, T., et al. (2014). The SEED and the rapid annotation of microbial genomes using subsystems technology (RAST). Nucleic Acids Res. 42, D206-14. doi: 10.1093/nar/gkt1226

Pallela, R., Koigoora, S., Gunda, V. G., Sunkara, M. S., and Janapala, V. R. (2011). Comparative morphometry, biochemical and elemental composition of three marine sponges (Petrosiidae) from Gulf of Mannar, India. Chem. Speciat. Bioavailab. 23, 16-23. doi: 10.3184/095422911X12966340771966

Patil, C. D., Patil, S. V., Salunke, B. K., and Salunkhe, R. B. (2011). Prodigiosin produced by Serratia marcescens NMCC46 as a mosquito larvicidal agent against Aedes aegypti and Anopheles stephensi. Parasitol. Res. 109, 1179-1187. doi: 10.1007/s00436-011-2365-9

Pawlik, J. R., Kernan, M. R., Molinski, T. F., Harper, M. K., and Faulkner, D. J. (1988). Defensive chemicals of the Spanish dancer nudibranch Hexabranchus sanguineus and its egg ribbons: macrolides derived from a sponge diet. J. Exp. Mar. Bio. Ecol. 119, 99-109. doi: 10.1016/0022-0981(88)90225-0

Perović, S., Krasko, A., Prokic, I., Müller, I. M., and Müller, W. E. (1999). Origin of neuronal-like receptors in Metazoa: cloning of a metabotropic
glutamate/GABA-like receptor from the marine sponge Geodia cydonium. Cell Tissue Res. 296, 395-404. doi: 10.1007/s004410051299

Prlić, A., Yates, A., Bliven, S. E., Rose, P. W., Jacobsen, J., Troshin, P. V., et al. (2012). BioJava: an open-source framework for bioinformatics in 2012. Bioinformatics 28, 2693-2695. doi: 10.1093/bioinformatics/bts494

Ramesh, C., Vinithkumar, N. V., and Kirubagaran, R. (2019a). Marine pigmented bacteria: a prospective source of antibacterial compounds. J. Nat. Sci. Biol. Med. 10, 104-113. doi: 10.4103/jnsbm.JNSBM_201_18

Ramesh, C., Vinithkumar, N. V., Kirubagaran, R., Venil, C. K., and Dufossé, L. (2019b). Multifaceted applications of microbial pigments: current knowledge, challenges and future directions for public health implications. 7:186. doi: 10.3390/microorganisms7070186

Sajjad, W., Ahmad, S., Aziz, I., Azam, S. S., Hasan, F., and Shah, A. A. (2018). Antiproliferative, antioxidant and binding mechanism analysis of prodigiosin from newly isolated radio-resistant Streptomyces sp. strain WMA-LM31. Mol. Biol. Rep. 45, 1787-1798. doi: 10.1007/s11033-018-4324-3

Sakai-Kawada, F. E., Ip, C. G., Hagiwara, K. A., and Awaya, J. D. (2019). Biosynthesis and bioactivity of prodiginine analogs in marine bacteria, pseudoalteromonas: a mini review. Front. Microbiol. 10, 1-9. doi: 10.3389/fmicb.2019.01715

Sakai-Kawada, F. E., Yakym, C. J., Helmkampf, M., Hagiwara, K., Ip, C. G., Antonio, B. J., et al. (2016). Draft genome sequence of marine sponge symbiont Pseudoalteromonas luteoviolacea IPB1, Isolated from Hilo, Hawaii. Genome Announc. 4, e01002-e01016. doi: 10.1128/genomeA.01 002-16

Salem, S. M., Kancharla, P., Florova, G., Gupta, S., Lu, W., and Reynolds, K. A. (2014). Elucidation of final steps of the marineosins biosynthetic pathway through identification and characterization of the corresponding gene cluster. J. Am. Chem. Soc. 136, 4565-4574. doi: 10.1021/ja411544w

Schmitt, S., Angermeier, H., Schiller, R., Lindquist, N., and Hentschel, U. (2008). Molecular microbial diversity survey of sponge reproductive stages and mechanistic insights into vertical transmission of microbial symbionts. Appl. Environ. Microbiol. 74, 7694-7708. doi: 10.1128/AEM.00878-08

Schupp, P., Eder, C., Paul, V., and Proksch, P. (1999). Distribution of secondary metabolites in the sponge Oceanapia sp. and its ecological implications. Mar. Biol. 135, 573-580. doi: 10.1007/s002270050658

Soliev, A. B., Hosokawa, K., and Enomoto, K. (2011). Bioactive pigments from marine bacteria: applications and physiological roles. Evidence-based Complement. Altern. Med. 2011. doi: 10.1155/2011/670349

Steinbeck, C., Han, Y., Kuhn, S., Horlacher, O., Luttmann, E., and Willighagen, E. (2003). The chemistry development kit (CDK): an open-source java library for chemo-and bioinformatics. J. Chem. Inf. Comput. Sci. 43, 493-500. doi: 10.1021/ci025584y

Tan, K., Zhang, H., Lim, L. S., Ma, H., Li, S., and Zheng, H. (2020). Roles of Carotenoids in Invertebrate Immunology. Front. Immunol. 10, 1-10. doi: 10.3389/fimmu.2019.03041

Treangen, T. J., Maybank, R. A., Enke, S., Friss, M. B., Diviak, L. F., David, D. K., et al. (2014). Complete genome sequence of the quality control strain Staphylococcus aureus subsp. aureus ATCC 25923. Genome Announc. 2, 25923. doi: 10.1128/genomeA.01110-14

Tuli, H. S., Chaudhary, P., Beniwal, V., and Sharma, A. K. (2015). Microbial pigments as natural color sources: current trends and future perspectives. J. Food Sci. Technol. 52, 4669-4678. doi: 10.1007/s13197-014-1601-6

Venil, C. K., Aruldass, C. A., Dufossé, L., Zakaria, Z. A., and Ahmad, W. A. (2014). Current perspective on bacterial pigments: emerging sustainable compounds with coloring and biological properties for the industry-an incisive evaluation. RSC Adv. 4, 39523-39529. doi: 10.1039/c4ra06162d

Waddell, B., and Pawlik, J. R. (2000). Defenses of Caribbean sponges against invertebrate predators. II. Assays with sea stars. Mar. Ecol. Prog. Ser. 195, 133-144. doi: 10.3354/meps195133

Webster, N. S. (2007). Sponge disease: a global threat? Environ. Microbiol. 9, 1363-1375. doi: 10.1111/j.1462-2920.2007.01303.x

Webster, N. S., and Taylor, M. W. (2012). Marine sponges and their microbial symbionts: love and other relationships. Environ. Microbiol. 14, 335-346. doi: 10.1111/j.1462-2920.2011.02460.x

Wiens, M., Korzhev, M., Krasko, A., Thakur, N. L., Perović-Ottstadt, S., Breter, H. J., et al. (2005). Innate immune defense of the sponge Suberites domuncula against bacteria involves a MyD88-dependent signaling pathway: 
induction of a perforin-like molecule. J. Biol. Chem. 280, 27949-27959. doi: 10.1074/jbc.M504049200

Wiens, M., Korzhev, M., Perović-Ottstadt, S., Luthringer, B., Brandt, D., Klein, S., et al. (2007). Toll-like receptors are part of the innate immune defense system of sponges (Demospongiae: Porifera). Mol. Biol. Evol. 24, 792-804. doi: 10.1093/molbev/msl208

Williamson, N. R., Fineran, P. C., Leeper, F. J., and Salmond, G. P. C. (2006). The biosynthesis and regulation of bacterial prodiginines. Nat. Rev. Microbiol. 4, 887-899. doi: 10.1038/nrmicro1531

Xu, F., Gage, D., and Zhan, J. (2015). Efficient production of indigoidine in Escherichia coli. J. Ind. Microbiol. Biotechnol. 42, 1149-1155. doi: $10.1007 / \mathrm{s} 10295-015-1642-5$

Yuen, B., Bayes, J. M., and Degnan, S. M. (2013). The characterization of sponge NLRs provides insight into the origin and evolution of this innate immune gene family in animals. Mol. Biol. Evol. 31, 106-120. doi: 10.1093/molbev/mst174

Zhang, H., Wang, H., Zheng, W., Yao, Z., Peng, Y., Zhang, S., et al. (2017). Toxic effects of prodigiosin secreted by Hahella sp. KA22 on harmful alga Phaeocystis globosa. Front. Microbiol. 8, 1-12. doi: 10.3389/fmicb.2017.00999
Ziemert, N., Podell, S., Penn, K., Badger, J. H., Allen, E., and Jensen, P. R. (2012). The natural product domain seeker NaPDoS: a phylogeny based bioinformatic tool to classify secondary metabolite gene diversity. PLOS ONE 7, 1-9. doi: 10.1371/journal.pone.0 034064

Conflict of Interest: The authors declare that the research was conducted in the absence of any commercial or financial relationships that could be construed as a potential conflict of interest.

Copyright (c) 2020 Sakai-Kawada, Ip, Hagiwara, Nguyen, Yakym, Helmkampf, Armstrong and Awaya. This is an open-access article distributed under the terms of the Creative Commons Attribution License (CC BY). The use, distribution or reproduction in other forums is permitted, provided the original author(s) and the copyright owner(s) are credited and that the original publication in this journal is cited, in accordance with accepted academic practice. No use, distribution or reproduction is permitted which does not comply with these terms. 